\title{
Tijdschrift Sociologie
}

Tijdschrift Sociologie 1: 22-27

(c) de auteur(s) 2020 ๑ CC BY NC ND 4.0 (ㅇ) (c) (7)

https://doi.org/10.38139/TS.2020.04

www.tijdschriftsociologie.eu

\section{Boekbespreking \\ Dwars door Bourdieus denken}

\author{
Daan Vandenhaute \\ Universiteit Gent \\ daan.vandenhaute@ugent.be
}

Édouard Louis (red.) (2016) Pierre Bourdieu. L'insoumission en héritage.

Paris: Presses Universitaire de France. 160 pagina's, €28,82,

Édouard Louis (red.) (2018) Pierre Bourdieu. Weerspannigheid als erfenis (vertaling llse Barendregt).

Amsterdam: Editie Leesmagazijn.

162 pagina's, €19,95,

ISBN 9789491717550.
In Nedstörtad ängel, een wat obscure parel van de Zweedse literatuur, door Rita Törnqvist in het Nederlands vertaald als Verbannen engel, dicht Per Olov Enquist $(1985 ; 1987)$ Ruth Berlau - auteur, regisseur, acteur, liefdesgezel van Bertolt Brecht - de volgende gedachten toe: 'Ze wou immers dat men haar zou zien. Een mens kan leven zonder te kunnen zien, ook een blinde is mens. Maar word je niet gezien, dan ben je niets.' Zo kan het klinken in de periferie; in het centrum - of wat het ooit is geweest - kan dat kernidee als volgt worden verwoord: 'Le monde social donne ce qu'il y a de plus rare, de la reconnaissance, de la considération, c'est-à-dire, tout simplement, de la raison d'être' (Bourdieu 1997: 345). Als socioloog van de ongelijkheid, een pleonasme, voegt Bourdieu er onmiddellijk aan toe: 'De toutes les distributions, l'une des plus inégales et, sans doute, en tout cas, la plus cruelle est la répartition du capital symbolique, c'est-à-dire de l'importance sociale et de raisons de vivre' (ibid.).

Dat kernidee is een Leitmotiv in de bundel Pierre Bourdieu. L'insoumission en héritage, geredigeerd door Édouard Louis, en recent vertaald door Ilse Barendregt, als Weerspannigheid als erfenis, een publicatie van Editie Leesmagazijn. Als geheel wordt de bundel gekenmerkt door grilligheid, met bijdragen als een theoretisch-filosofisch traktaat over de betekenis van Spinoza voor een goed begrip van Bourdieus sociolo- 
gische denken, een kritische reflectie over de concrete politieke stellingnames van Bourdieu in het Franse sociale debat op het einde van de vorige eeuw, een persoonlijk doorleefde maar tekstgetrouwe lezing van La distinction of een door Bourdieus denken gekleurde autobiografische schets over politiek en leven vanuit het perspectief van de 'klassenmigrant'.

De aanleiding voor deze bundel - zo leert een voetnoot van de vertaler in de Nederlandse uitgave - is een colloquium ter herdenking van het tienjarige overlijden van Bourdieu (de publicatie in de Quadrige-reeks is dus met enige vertraging verschenen). Dat het colloquium ook een hommage aan Bourdieu was, blijkt het duidelijkst uit de laatste bijdrage in de bundel, een tekst van Pierre Bergounioux, Frans auteur-beeldhouwer, typerend voor de bundel voorgesteld als middelbareschoolleerkracht en vervolgens docent aan de École des Beaux-Arts in Parijs en 'tegenwoordig gepensioneerd'. Die ultieme hommage is zeker geen hagiografie; het eerbetoon wordt voor een stuk zelfs ondermijnd door de schriftuur; het taalgebruik, de stijl, de manier van vertellen, onder meer via een omweg langs antieke Griekse helden, geven de tekst - en zijn hoofdpersonage - een fictief karakter. Bergounioux wijst ten overvloede op het zo belangrijke in het sociale verkeer van het - in empirische studies nauwelijks te 'operationaliseren', maar voor ieder van ons zo (her) kenbare - 'je-ne-sais-quoi dat goeie jongens en brave meisjes maakt en, als dat ontbreekt, klootzakken en rotwijven, met wie je liever alle omgang mijdt' (Weerspannigheid, p. 164).

De tekst van Bergounioux gaat verder dan de anekdotiek, en biedt op eigenzinnige wijze een concies maar goed overzicht van Bourdieus leven en denken, met oog voor de kern ervan - zoals die in elk geval doorheen deze bundel wordt gethematiseerd, met name dat

[...] de sociologie van Bourdieu aan zijn scholing als filosoof, evenals aan zijn onvervangbare, pijnlijke, vruchtbare en beslissende ervaring van de maatschappelijke en geografische achterstelling, een revolutionaire kracht [ontleent]. Die sociologie betwist en weerlegt de voorstellingen die de orde der dingen reproduceren en waarborgen (Weerspannigheid, p. 175).

L'insoumission en héritage is zeker niet bedoeld als een Bourdieu-companion, maar in zekere zin fungeert de bundel wel als een wegwijzer; niet de zoveelste, maar wel een door auteurs met heel diverse achtergrond - een diversiteit die op zich exemplarisch is voor de spanwijdte van Bourdieus sociologie - die ingeleefd vertrouwd zijn met het denken van Bourdieu en die oog hebben voor de 'menselijke' dimensie van dat denken, de strijdbare passie, die ook tot uiting komt in Bourdieus politieke stellingname en actie. (In die zin is een bijdrage zoals die van John Levi Martin in het recente prestigieuze Oxford Handbook of Pierre Bourdieu (Martin 2018) in deze bundel ondenkbaar; niet omdat die bijdrage een theoretische is, wel omdat zijn tekst - een reflectie over het veldconcept, waaruit het antagonistische, het veld als 
strijdveld, is weggezuiverd - voorbij gaat aan de essentie van Bourdieus sociologie, een analyse van de macht, het arbitraire van overheersing en de noodzaak van verzet.)

Hoe divers de bundel ook is, de bijdragen kunnen mijns inziens geclusterd worden in drie groepen, naargelang van het dominante accent dat elke bijdrage typeert: doorleefde ervaring, politieke actie of theoretische reflectie.

De bijdragen van Annie Ernaux en Édouard Louis getuigen van een persoonlijke, lijfelijk ervaren herkenning van Bourdieus denken, een empathie ingegeven door gelijkaardige vertrekpunten in de sociale ruimte. Ernaux doet verslag van haar leeservaring met La distinction (Bourdieu 1979) en bespreekt met rake observaties de grote lijnen van dat werk. Wie voor een reader cultuursociologie op zoek is naar een interessante introductie tot een van Bourdieus hoofdwerken vindt hier wat zij/ hij nodig heeft.

Ook Louis vertrekt in zijn bijdrage van persoonlijke ervaringen, met name de angst (niet 'een vage vrees of een gevoel van verwarring zoals je die in de heersende klassen tegenkomt naar aanleiding van een nieuwe hervorming, maar [...] een ware angst, een staat van verslagenheid door het zekere besef dat we niet meer zouden rondkomen' - Weerspannigheid, p. 8), die in zijn kinderjaren de politieke klasse de omgeving waarin hij opgroeide inboezemde. Louis gaat in op de diepe kloof tussen 'leven' en 'politiek', opgevat als loutere 'communicatie' - boven de hoofden van diegenen die niet kunnen deelnemen aan die communicatie en zonder repercussies voor de levens van diegenen die er wel aan deelnemen, in tegenstelling tot voor wie niet aan het spel kan deelnemen.

Het is dus zeker niet zo dat de teksten van Louis en Ernaux apolitiek zijn. Zo wijst ook Ernaux erop dat 'Bourdieus analytische hulpmiddelen namelijk ook instrumenten van vrijheid [zijn], aansporingen om in te grijpen in de wereld, om zich niet neer te leggen bij "dat wat is"' (Weerspannigheid, p. 56). Maar de focus ligt er minder op Bourdieus concrete politieke ingrijpen, het thema in de bijdragen van Didier Eribon en Frédéric Lebaron.

De tekst van Eribon vertrekt vanuit een reflectie over een concrete politieke actie - een manifest dat Bourdieu schreef in mei 1968 - maar meandert, naar het beeld van de bundel in zijn geheel, breder en kaart verschillende aspecten aan die ook in andere bijdragen resoneren. In zijn reflectie over Bourdieus relatie tot de sociale strijd beklemtoont Eribon drie aspecten: (1) het belang van zelfreflectie (en de rol die de kritische socioloog/intellectueel daarbij kan en moet spelen, hoe problematisch die zelfreflectie ook kan zijn - getuige bijvoorbeeld de vehemente reacties vanuit feministische hoek op Bourdieus analyse van de mannelijke onderdrukking in La domination masculine (1998)), (2) het idee van sociale bewegingen als avant-garde, naar het model van de esthetische revoluties, waarbij 'de subversieve kracht van afzonderlijke bewegingen in dienst zou moeten worden gesteld van het universele' (Weerspannigheid, p. 155; wat dat universele dan precies is en hoe een en ander kan worden bereikt blijven onbeantwoorde vragen) en (3) het probleem van de zelfuitsluiting, het symbolische geweld, de vraag van de gewillige onderwerping, 'die door 
elk denken dat kritisch wil zijn heen loopt' (Weerspannigheid, p. 147), maar die ook hier geen antwoord krijgt.

De (korte) tekst van Lebaron, die vreemd genoeg niet is opgenomen in de vertaalde bundel, bespreekt een gelijkaardige problematiek, maar koppelt die aan Bourdieus concrete politieke handelen aan het einde van de twintigste eeuw, politieke avant-garde in actie, kritisch geanalyseerd door Lebaron, die een dubbel probleem opmerkt: het probleem van de radicale symbolische actie zonder draagvlak en het probleem 'de ne pas suffisamment tenir compte des pesanteurs sociologiques qu'il n’avait cessé d'analyser' (L'insoumission, p. 83).

Ook al loopt persoonlijke beleving gekoppeld aan reflectie over de kritische, politieke dimensie van Bourdieus denken als een rode draad doorheen de hele bundel, hebben drie teksten, ten slotte, toch vooral een wat meer theoretisch, beschouwend karakter.

Frédéric Lordon neemt in zijn uitgebreide bijdrage ogenschijnlijk het verst afstand van Bourdieu, om duiding te geven bij een van zijn centrale ideeën, dat van het symbolisch geweld, het inzicht dat de overheersten instemmen in hun overheersing. Lordon knoopt hiervoor aan bij Spinoza en zijn uiteenzettingen over de conatus, de begeerte, en de affecten, die de invulling van die drijfkracht bepalen. Lordon vindt bij Spinoza een manier 'om over individuele mensen [te] spreken zonder tot de vooroordelen van het (theoretisch) humanisme te vervallen of het gewicht van de - vooral structurele - determinaties, dat onophoudelijk op hen drukt, uit het oog te verliezen' (Weerspannigheid, p. 122). Met het concept van de habitus opende Bourdieu de weg om Durkheims opvatting dat 'de psychologie op plaatselijk niveau uitdrukking geeft aan de sociologie' veel genuanceerder te begrijpen, maar voor Lordon houdt een 'spinozistisch onderzoeksprogramma binnen de sociale wetenschappen' de belofte in om die weg voluit te gaan (Weerspannigheid, pp. 122-124)

In de kortere tekst van Arlette Farge wordt de beschouwing volledig gewijd aan het controversiële La domination masculine (Bourdieu 1998). Ze duidt die controverse en wijst als historica op de uitdaging waar Bourdieu het historisch onderzoek voor stelt, met name het 'vastleggen en opschrijven hoe de geschiedenis van de instandhouding zich door de geschiedenis van de veranderingen heen voltrekt' (Weerspannigheid, p. 68). Dat zo'n opdracht onverbiddelijk kan zijn, en een uitdaging aan de hoop, beschrijft Farge met een treffend beeld, als ze het gevoel dat een lezer van La domination masculine kan hebben vergelijkt met dat van een vlinder, opgeprikt aan een muur, met nog slaande vleugels.

Ook Geoffroy de Lagasnerie staat stil bij de negatieve reacties die Bourdieus sociologie opwekken. Die gevoelens van weerstand worden voor de Lagasnerie niet ingegeven door het feit dat Bourdieu met zijn sociologische analyse de verdrongen waarheid zou blootleggen, maar wel door zijn specifieke kijk op de wereld, 'de nieuwe opvatting van de mens en de menselijke verhoudingen die door de sociologische denkwijze wordt geconstrueerd' en de wereld 'zwaar' maakt. (Weerspannigheid, pp. 74-75). Het verontrustende zit in wat de Lagasnerie de 'oorlogsvisie en de tragische kijk' noemt. In het denken van Bourdieu staan strijd en conflict centraal, waarbij 
de sociologie zich verzet 'tegen de paradigma's die de wereld in functionele termen benaderen, die denken in termen van harmonie, complementariteit, samenleven, sociale verbondenheid enzovoorts' (Weerspannigheid, p. 75). Daarbovenop gaat Bourdieu uit van een opvatting van de mens als een Sein zum Tode, de mens als absurd, contingent en willekeurig wezen, dat om aan die zinloosheid te ontsnappen op zoek gaat naar erkenning, een sociale identiteit. Bourdieus analyse verontrust omdat ze dat hele spel van erkenning demystificeert, de willekeur ervan blootlegt en het op die manier plaatst 'aan de kant van het geloof, de fictie en dus, in zekere zin, de absurditeit' - waarvan ze ons nu net moest bevrijden (Weerspannigheid, p. 78). In zijn bijdrage legt de Lagasnerie de klemtoon op de maatschappelijke erkenning, zoals die uitgedrukt wordt in officiële onderscheidingen, titels, maar ook in functies et cetera. Bourdieu daarentegen, stelt de Lagasnerie, nodigt ons uit om 'na te denken over een andere manier om naar onszelf en onze verhouding tot anderen te kijken' (Weerspannigheid, p. 82). En vandaar, aldus de Lagasnerie, dat het autonomieconcept zo'n belangrijke rol speelt bij Bourdieu. Het voorbeeld van de autonome kunstenaar of intellectueel biedt volgens de Lagasnerie een manier om te 'ontsnappen aan de vervreemdende dialectiek van de erkenning, jezelf (te) onttrekken aan de invloed die instituties en officiële consecraties op het denken uitoefenen' (Weerspannigheid, p. 83). Dit is, op zijn minst gezegd, een eigenzinnige interpretatie van Bourdieus autonomieconcept, die abstractie makt van heel zijn productie-van-geloof-analyse. Maar dat zo'n interpretatie van de avant-garde, niet als een positie in het strijdveld, maar als een plek erbuiten, waar het particuliere het universele wordt, überhaupt mogelijk is, komt natuurlijk door de spanning tussen die twee opvattingen die ook voelbaar is in het werk van Bourdieu. Denk bijvoorbeeld aan De regels van de kunst (1994), waarin Bourdieu het veldbegrip centraal plaats en de voortdurende strijd om de relatieve waarde(n) van literatuur en kunst, en het postscriptum in dat zelfde boek waarin Bourdieu vanuit een absolute positie een pleidooi houdt voor een corporatisme van het universele.

Bourdieu eindigt zijn Schets voor een zelfanalyse met de verzuchting dat

[...] niets mij gelukkiger [zou] maken als het mij zou lukken enkele van mijn lezers of lezeressen hun ervaringen, hun moeilijkheden, hun vraagtekens en hun beproevingen te doen herkennen in die van mij, en hen met deze realistische identificatie, die niets van doen heeft met een dweperige vorm van projectie, de middelen te bieden om te handelen en te leven, en dat een beetje beter te doen (Bourdieu 2015: 116-117).

Ik denk dat L'insoumission en héritage ampele indicatie geeft dat dit geen ijdele hoop is, maar ook voor wie minder begaan is met het (postume) geluk van deze of gene, biedt deze bundel heel wat interessante inzichten in een denken dat nog lang niet dood is. 


\section{Literatuur}

Bourdieu, Pierre (1979) La Distinction. Critique sociale du jugement. Paris: Les Éditions de Minuit.

Bourdieu, Pierre (1997) Méditations pascaliennes. Paris: Éditions du Seuil.

Bourdieu, Pierre (1994) De regels van de kunst. Wording en structuur van het literaire veld (vertaling Rokus Hofstede). Amsterdam: Van Gennep.

Bourdieu, Pierre (1998) La domination masculine. Paris: Éditions du Seuil.

Bourdieu, Pierre (2015) Schets voor een zelfanalyse (vertaling Anton Wesselingh). Antwerpen: Garant.

Enquist, Per Olov (1985) Nedstörtad ängel: en kärleksroman. Stockholm: Norstedts.

Enquist, Per Olov (1987) Verbannen engel (vertaling Rita Törnqvist). Utrecht: Flint.

Martin, John Levi (2018) Bourdieu’s Unlikely Contribution to the Human Sciences. In: Thomas Medvetz and Jeffrey J. Sallaz (red.) Oxford Handbook of Pierre Bourdieu. Oxford: Oxford University Press.

\section{Over de auteur}

Daan Vandenhaute is als docent werkzaam aan de Universiteit Gent, vakgebied Zweedse letterkunde, met als onderzoeksinteresse de studie van het literaire veld, zowel vanuit het perspectief van productie als van consumptie. 